\title{
Effect of Storage Periods and Package Types on Germination, Seedling Characters and Biochemical Changes of Barley Grains
}

\author{
Mahmud A. A. Rahouma
}

\begin{abstract}
A lab experiment was conducted under natural conditions in Higher and Moderate Institute of Agricultural Technology Labs, Algheran, Libya to study storage period, package, type and their interactions effects on germination, seedling characters, infestation percent, and biochemical components of Sidi Almasry barley grains. Split-plot in completely randomized design in three replications was used. The most important results could be summarized as follows:

Increasing storage period up to six months decreased 1000-grains weight, falling number, seedling and radical length, however grain-moisture, protein, fat and ash contents and infestation percentage with Fusarium were significantly increased.

On the other hand, high density polyethylene bags significantly decreased 1000-grain weight $(39.47 \%)$, germination percent $(83.66 \%)$, seedling and radical length $(6.09$ and $7.99 \mathrm{~cm})$, falling number $(384.50)$ and grain protein content $(11.97 \%)$, however, this type of package increased grain moisture content $(\mathbf{1 2 . 4 7 \% )}$ ) and Fusarium infestation percent $(\mathbf{8 . 4 7 \%})$.

Interaction between the two factors indicated that barley grains stored for six months in high density polyethylene significantly decreased 1000-grain weight, germination percent, falling number and increased Fusarium infestation percent, grain moisture and protein contents. Conversely, storage barley grains in jute bags for six months can alleviate the adverse effects on warehouse and other studied package types.
\end{abstract}

Keywords: storage period, package type, barley, germination, biochemical contents.

\section{INTRODUCTION}

Barley (Hordeum vulgare L.) is considered one of the most important cereal crops in the world as well as in Libya. It ranks fourth in the world cereal crop production after wheat, rice and maize. In many parts in the world, it is used for feeding animal (both grains and straw) and malt production. Barley grains is used for preparing the most popular diets in Libya (Mazeen), packing bread as it is or by mixing with wheat flour in some places in Egypt and some human food and beverages and many other uses. Because of its short life cycle, morphological, physiological and genetic characteristics, compared with other cereal crops, barley grows well under the drought conditions in arid and semi-arid regions because its plants tolerate moderate levels of water stress (Ouda et al., 2005).

Careful barley grains storage can help in alleviating problems of seed viability and marketing for long period. Barley grains may be safely stored from harvest to planting by under suitable temperature and relative humidity conditions. Factors as temperature, moisture, variety and nutrient status influence seed maturity, which, in turn, influence seed storability (Copeland and McDonald, 1995). Storage time and conditions may induce some physical, chemical and biochemical alterations in storage soybean seeds (Narayan et al., 1988 a). Each package material has special characteristics and relationship with the stored seeds (Justice and Bass, 1979). Ismail et al. (1988) reported that storage of raw rice grains in polyethylene bags at room temperature was the best compared with convential silos and burlap bags.

This investigation aimed to study the effect of storage period and package type on germination, seedling characters and biochemical components of barley grains.

\section{MATERIALS AND METHODS}

The present investigation was carried out in Higher and Moderate Institute of Agricultural Technology Labs, Algheran, Libya to study the effect of storage period and package type on germination, seedling characters and biochemical components of barley grains during the $1^{\text {st }}$ May to $1^{\text {st }}$ December, 2020. At harvest (mid-April, 2020), samples of barley grains of Sidi Almasry variety were randomly taken $(20 \mathrm{~kg})$ and equally divided on four packages made from different materials,i.e., warehouse (no packing) $\left(D_{1}\right)$, jute $\left(D_{2}\right)$, high density polyethylene $\left(\mathrm{D}_{3}\right)$ and woven polyethylene $\left(D_{4}\right)$ as sub-plot treatments. Each package was filled with $5 \mathrm{~kg}$ and stored for seven months. Random grain samples were taken from each package at the beginning of storage, two, four and six months $\left(\mathrm{P}_{1}, \mathrm{P}_{2}, \mathrm{P}_{3}\right.$ and $\left.\mathrm{P}_{4}\right)$ as main plot treatments. These samples were subjected to germination, seedling characters, biochemical components and Fusarium moniliforme infestation percent.

\footnotetext{
DOI: 10.21608/asejaiqjsae.2021.152593

${ }^{1}$ Higher and Moderate Institute of Agricultural Technology, Algheran, Libya

Received January19, 2021, Accepted, February 28, 2021.
} 
Data were statistically analyzed according to splitplot (completely randomized design) with three replicates.

Standard germination test was carried out under optimum conditions according to (ISTA, 1999). Chemical composition characters, i.e. protein, ash, fat and moisture contents and falling number were determined according to A.O.A.C. (1990). Analysis of variance was computed according to Gomez and Gomez (1984).

Table (1) present the meteorological data including minimum and maximum centigrade temperature and relative humidity (\%) during the storage period at Tripoli (Lybia).

Table 1. Meteorological data (minimum and maximum temperature and relative humidity percent from April to November 2020 at Tripoli (Lybia)

\begin{tabular}{|c|c|c|c|}
\hline \multirow{2}{*}{ Month } & \multicolumn{2}{|c|}{ Air temperature ${ }^{\circ} \mathrm{C}$} & \multirow{2}{*}{$\begin{array}{c}\text { Relative } \\
\text { humidity } \\
(\%)\end{array}$} \\
\hline & Minimum & Maximum & \\
\hline April & 16 & 29 & 51 \\
\hline May & 19 & 28 & 54 \\
\hline June & 20 & 29 & 62 \\
\hline July & 25 & 32 & 71 \\
\hline August & 23 & 31 & 78 \\
\hline September & 21 & 29 & 68 \\
\hline October & 22 & 29 & 60 \\
\hline November & 17 & 28 & 56 \\
\hline
\end{tabular}

Data were obtained from www.wunderground.com

\section{RESULTS AND DISCUSSION}

Results presented in Table (2) showed that increasing storage period of Sidi Almasry barley grains up to six months significantly, and gradually, decreased 1000-grain weight, germination percentage, seedling and radical length, and falling number. Decreasing percentages after six months $\left(\mathrm{P}_{4}\right)$ were $7.42 \%, 16.55 \%$, $54.97 \%, 53.82 \%$ and $19.94 \%$, for the previous traits, respectively, compared with $\left(\mathrm{P}_{1}\right)$. Conversely, increasing storage period from $\left(\mathrm{P}_{1}\right)$ up to $\left(\mathrm{P}_{4}\right)$ gradually and significantly increased grain moisture content by $(2.56 \%)$, protein content by $(1.38 \%)$, fat and ash content by $(1.47 \%$ and $0.64 \%)$ and infestation percentage of grains $(14.43 \%)$ compared with $\left(\mathrm{P}_{1}\right)$. Increasing storage period up to six months $(\mathrm{P} 4)$ under high relative humidity $(51 \% \leq)$ and maximum air temperature $\left(28^{\circ} \mathrm{C} \leq\right)$, as shown in Table (1), could accelerate grain respiration and consequently destruct complex molecules such as starch thus decreasing grain weight, germination percentage and seedling and radical length.
In contrast, increasing grain moisture content up to $(12.87 \%)$ after six months led to increase of infestation percent with Fusarium. On the other hand, decrease in falling number was related to increase $\alpha$-amylase anzyme activity and decrease starch content and increase other grain contents such as protein, ash and fat.

These findings are in agreement with those obtained by El-Sayed (1997), Al-Aidy et al. (2001) and El-Sayed et al. (2004) for germination percent and 1000-grain weight, Tomar and Singh (1986). Odiemah and Hafez (1990) and El-Borai et al. (1993) for seedling and radical length, Pixton (1980). Chrastil (1990), El-Borai et al. (1993) and Deka and Soad (2001) for grain protein and fat content, Mehmet et al. (2009) for falling number and El-Aidy et al. (2001), Tolba and El-Sayed (2002) and El-Sayed et al. (2004) for infestation percent with Fusarium moniliforme.

Concerning type of package effect on the studied barley grain characteristics, results presented in Table (2) revealed that all studied traits were significantly affected by package type, except grain ash content. High density polyethylene package $\left(\mathrm{D}_{3}\right)$ produced the lowest 1000-grain weight $(39.47 \mathrm{~g})$, least germination percentage $(83.66 \%)$, shortest seedling and radical length $(6.09$ and $7.99 \mathrm{~cm})$, protein content $(11.97 \%)$ and falling number (384.50), however that package type showed the highest grain moisture content $(12.47 \%)$ and highest Fusarium infestation percentage $(8.47 \%)$. That could be due to these bags are characterized with very low permeability and that led to increase grain respiration rate, especially under high air temperature $\left(33^{\circ} \mathrm{C} \leq\right)$ as shown in Table (1). These storage conditions increased grain moisture content and consequently infestation percent and deterioration of germination, growth and chemical components of grains and falling number as an indication of increasing $\alpha-$ amylose enzyme activity.

On the contrary, Sidi Almasry barely grains stored in jute package gave the heaviest 1000-grain weight (40.37 $\mathrm{g})$, tallest seedling and radical $(7.09$ and $8.22 \mathrm{~cm})$ and highest falling number (403.75). That package type, also showed the lowest moisture content (10.90\%), protein and fat content (11.67\% and 3.37\%) and Fusarium infestation percent $(3.81 \%)$. That woven jute fibers are characterized by high permeability that allow moisture loss and make stored grains more dry, in addition jute fibers had strong absorption ability of moisture that can help for drying stored grains and consequently less infection with fusarium disease. Similar results were obtained by Saeeda et al. (2010) for grain moisture content and 1000-kernel weight and Ali (2012) for seedling and radical length. 
With regard to storage period $\times$ package material interactions, results presented in Table (2) revealed significant interactions effect on all the studied traits, and that means that the four package materials differently responded to storage period. Considering 1000-grain weight, ware house grains or stored in Jute package at the beginning of storage $\left(\mathrm{P}_{1}\right)$ produced the heaviest 1000- grain weight (40.79 and $40.37 \mathrm{~g})$, respectively. Conversely, increasing storage period up to six months $\left(\mathrm{P}_{4}\right)$ significantly decreased those traits in all the studied package materials, especially that stored in high density polyethylene (37.76 g). That could be due to increasing of grain respiration rate in those bags. Similar results were reported by Baskin et al. (1987). On the other hand, the highest germination percentage and seedling length values resulted at the beginning of barely grains storage $\left(\mathrm{P}_{1}\right)$ without significant differences between the studied package materials. However, the lowest germination percent (74.89) resulted from storage grains in high density polyethylene for six months and the shortest barley seedlings resulted from storage of grains, within any studied package for six months. Concerning radical length, storage of barley grains in jute packages at the beginning of storage produced the tallest radical $(12.09 \mathrm{~cm})$, while shortest radicals resulted from storage of grains, in any studied package for six months. These results are in harmony with those obtained by Odiemah and Hafez (1990) and El-Borai et al. (1993).

With respect to the effect of interaction between storage period and package type on grain moisture content, results presented in Table (2) showed that, at the beginning of storage, stored grains in jute package contained the lowest moisture content $(10 \%)$, however the highest moisture content $(14.64 \%)$ resulted from storaging grains in high density polyethylene $\left(D_{3}\right)$ for six months which was correlated with the highest infestation percent (19.46\%) with Fusarium moniliforme. Similar results were reported by Arya (2002), who suggested that moisture content of grains stored in jute bags was significantly increased with increasing storage period.
Interaction between the two studied factors (Table 2) revealed that the longest storage period (six months) showed the highest protein, fat and ash contents in barley grains stored in all studied packages, except jute for protein content, warehouse and woven polyethylene for fat content and warehouse for ash content. On the contrast, the lowest grain protein and fat contents (11.51 and $3.09 \%$ ), respectively, were produced from packing barley grains in jute packages at $\left(\mathrm{P}_{1}\right)$ period, however storage of Sidi Almasry barley grains in any of the studied packages for two months produced the lowest ash content. On the other hand, at the beginning of storage any studied package types produced the highest falling number (indication for low $\alpha$-amylase activity in liquefying starch), while storing barley grains in high density polyethylene $\left(D_{3}\right)$ or woven polyethylene $\left(D_{4}\right)$ for six months produced the lowest falling number (342 and 340), respectively.

The results obtained for the interaction effect between storage period and package type on viability, 1000-grain weight, seedling growth and chemical components of Sidi Almasry barley grains indicated that increasing storage period up to six months, in general, significantly increased grain moisture content that accelerated infection of grains with Fusarium fungi, and decreased falling number due to increase of $\alpha$-amylase activity in liquefying starch, consequently decreasing 1000 -grain weight and increasing grain protein, fat and ash contents compared to starch content. On the other hand, jute package led to decrease in grain moisture content after six months of storage, compared to the other three package types and consequently it could be used for storing barley grains for six months under high air temperature and humidity without risk of deterioration.

Hence, it could be concluded that jute packages are more suitable for storage of Sidi Almasry barley grains for six months under Algheran (Libya) environmental conditions. 
Table 2. Means of barley grain weight, germination percentage and its chemical components as influenced by storage periods, package and their interactions

\begin{tabular}{|c|c|c|c|c|c|c|c|c|c|c|c|}
\hline \multicolumn{2}{|c|}{ Factor } & $\begin{array}{c}\text { 1000- } \\
\text { grain } \\
\text { weight (g) }\end{array}$ & $\begin{array}{c}\text { Germination } \\
(\%)\end{array}$ & $\begin{array}{c}\text { Seedling } \\
\text { length } \\
(\mathrm{cm})\end{array}$ & $\begin{array}{c}\text { Radical } \\
\text { length } \\
(\mathrm{cm})\end{array}$ & $\begin{array}{c}\text { Moisture } \\
\text { content } \\
(\%)\end{array}$ & $\begin{array}{c}\text { Protein } \\
\text { content } \\
(\%)\end{array}$ & $\begin{array}{l}\text { Fat } \\
(\%)\end{array}$ & $\begin{array}{c}\text { Ash } \\
\text { content } \\
(\%)\end{array}$ & $\begin{array}{c}\text { Falling } \\
\text { number }\end{array}$ & $\begin{array}{c}\text { Infestation } \\
(\%)\end{array}$ \\
\hline \multicolumn{12}{|c|}{ Storage period (month) } \\
\hline $0\left(\mathrm{P}_{1}\right)$ & & $42.07^{\mathrm{a}}$ & $91.46^{\mathrm{a}}$ & $9.15^{\mathrm{a}}$ & $11.39^{\mathrm{a}}$ & $10.31^{\mathrm{d}}$ & $11.46^{\mathrm{d}}$ & $3.32^{\mathrm{c}}$ & $1.41^{\mathrm{c}}$ & $418.50^{\mathrm{a}}$ & $0.85^{\mathrm{d}}$ \\
\hline $2\left(\mathrm{P}_{2}\right)$ & & $40.69^{b}$ & $87.38^{b}$ & $8.17^{b}$ & $9.49^{b}$ & $11.17^{\mathrm{c}}$ & $11.65^{\mathrm{c}}$ & $3.34^{\mathrm{c}}$ & $1.42^{\mathrm{c}}$ & $405.50^{b}$ & $2.19^{c}$ \\
\hline $4\left(P_{3}\right)$ & & $39.61^{c}$ & $82.58^{c}$ & $6.53^{c}$ & $6.96^{c}$ & $12.11^{\mathrm{b}}$ & $12.04^{b}$ & $3.87^{b}$ & $1.82^{b}$ & $384.00^{\mathrm{c}}$ & $8.17^{\mathrm{b}}$ \\
\hline $6\left(\mathrm{P}_{4}\right)$ & & $38.95^{\mathrm{d}}$ & $76.32^{\mathrm{d}}$ & $4.12^{\mathrm{d}}$ & $5.26^{\mathrm{d}}$ & $12.87^{\mathrm{a}}$ & $12.84^{\mathrm{a}}$ & $4.79^{\mathrm{a}}$ & $2.05^{\mathrm{a}}$ & $355.00^{\mathrm{d}}$ & $15.28^{\mathrm{a}}$ \\
\hline \multicolumn{12}{|c|}{ Package type } \\
\hline Ware hou & & $40.79^{a}$ & $85.73^{\mathrm{a}}$ & $7.02^{\mathrm{ab}}$ & $8.18^{b}$ & $12.01^{\mathrm{b}}$ & $12.24^{b}$ & $4.02^{\mathrm{a}}$ & $1.72^{\mathrm{a}}$ & $389.50^{b}$ & $6.88^{b}$ \\
\hline Jute $\left(\mathrm{D}_{2}\right)$ & & $40.37^{\mathrm{a}}$ & $84.29^{b}$ & $7.09^{\mathrm{a}}$ & $8.82^{\mathrm{a}}$ & $10.90^{\mathrm{d}}$ & $11.67^{\mathrm{d}}$ & $3.37^{\mathrm{c}}$ & $1.62^{\mathrm{a}}$ & $403.75^{a}$ & $3.81^{\mathrm{c}}$ \\
\hline High den & lene $\left(D_{3}\right)$ & $39.47^{b}$ & $83.66^{c}$ & $6.09^{c}$ & $7.99^{c}$ & $12.47^{\mathrm{a}}$ & $11.97^{\mathrm{c}}$ & $3.92^{b}$ & $1.64^{\mathrm{a}}$ & $384.50^{\mathrm{c}}$ & $8.47^{\mathrm{a}}$ \\
\hline \multicolumn{12}{|c|}{ Interaction $(\mathrm{P} * \mathrm{D})$} \\
\hline \multirow{4}{*}{ 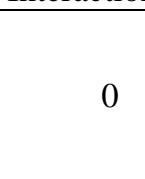 } & $\mathrm{D}_{1}$ & $42.87^{\mathrm{a}}$ & $91.19^{\mathrm{a}}$ & $9.17^{\mathrm{a}}$ & $11.23^{b}$ & $10.43^{f}$ & $11.56^{\mathrm{de}}$ & $3.40^{\mathrm{d}}$ & $1.40^{\mathrm{c}}$ & $420^{\mathrm{a}}$ & $1.00^{h}$ \\
\hline & $\mathrm{D}_{2}$ & $42.36^{\mathrm{ab}}$ & $91.33^{\mathrm{a}}$ & $9.20^{\mathrm{a}}$ & $12.19^{\mathrm{a}}$ & $10.00^{\mathrm{g}}$ & $11.51^{\mathrm{e}}$ & $3.09^{\mathrm{e}}$ & $1.42^{\mathrm{c}}$ & $418^{a b}$ & $0.50^{h}$ \\
\hline & $\mathrm{D}_{3}$ & $41.23^{b c}$ & $92.02^{\mathrm{a}}$ & $9.10^{\mathrm{a}}$ & $11.09^{b}$ & $10.44^{\mathrm{f}}$ & $11.20^{f}$ & $3.41^{\mathrm{d}}$ & $1.41^{\mathrm{c}}$ & $418^{b}$ & $0.90^{h}$ \\
\hline & $\mathrm{D}_{4}$ & $41.82^{b}$ & $90.31^{b}$ & $9.15^{\mathrm{a}}$ & $11.06^{\mathrm{b}}$ & $10.40^{\mathrm{fg}}$ & $11.60^{\mathrm{de}}$ & $3.38^{\mathrm{d}}$ & $1.41^{\mathrm{c}}$ & $421^{\mathrm{a}}$ & $1.00^{\mathrm{h}}$ \\
\hline \multirow{4}{*}{2} & $\mathrm{D}_{1}$ & $41.12^{\mathrm{c}}$ & $88.36^{c}$ & $8.22^{b}$ & $9.40^{\mathrm{d}}$ & $11.27^{\mathrm{e}}$ & $11.67^{\mathrm{de}}$ & $3.43^{\mathrm{d}}$ & $1.44^{\mathrm{c}}$ & $410^{c}$ & $2.52^{\mathrm{g}}$ \\
\hline & $\mathrm{D}_{2}$ & $40.74^{\mathrm{cd}}$ & $87.18^{\mathrm{d}}$ & $8.30^{b}$ & $9.92^{c}$ & $10.26^{\mathrm{fg}}$ & $11.59 \mathrm{de}$ & $3.15^{\mathrm{e}}$ & $1.44^{\mathrm{c}}$ & $406^{\mathrm{d}}$ & $1.11^{\mathrm{h}}$ \\
\hline & $\mathrm{D}_{3}$ & $39.88^{\mathrm{de}}$ & $86.17^{\mathrm{d}}$ & $8.07^{\mathrm{b}}$ & $9.27^{\mathrm{d}}$ & $11.96^{\mathrm{d}}$ & $11.70^{\mathrm{d}}$ & $3.42^{\mathrm{d}}$ & $1.42^{\mathrm{c}}$ & $400^{\mathrm{e}}$ & $3.13^{\mathrm{g}}$ \\
\hline & $\mathrm{D}_{4}$ & $41.02^{c}$ & $87.83^{\mathrm{cd}}$ & $8.09^{b}$ & $9.38^{\mathrm{d}}$ & $11.20^{\mathrm{e}}$ & $11.64 \mathrm{de}$ & $3.39^{\mathrm{d}}$ & $1.40^{\mathrm{c}}$ & $406^{\mathrm{d}}$ & $2.00^{\mathrm{gh}}$ \\
\hline \multirow{4}{*}{4} & $\mathrm{D}_{1}$ & $40.08^{\mathrm{d}}$ & $84.17^{\mathrm{e}}$ & $6.54^{c}$ & $6.92^{f}$ & $12.31^{\mathrm{d}}$ & $12.58^{b}$ & $4.05^{c}$ & $1.89^{\mathrm{b}}$ & $382^{\mathrm{g}}$ & $8.13^{\mathrm{e}}$ \\
\hline & $\mathrm{D}_{2}$ & 39.68 de & $82.25^{\mathrm{fg}}$ & $6.65^{c}$ & $7.32^{\mathrm{e}}$ & $11.20^{\mathrm{e}}$ & $11.60^{\text {de }}$ & $3.38^{\mathrm{d}}$ & $1.67 \mathrm{bc}$ & $399^{\mathrm{e}}$ & $5.14^{\mathrm{f}}$ \\
\hline & $\mathrm{D}_{3}$ & $39.02^{\mathrm{e}}$ & $81.56^{\mathrm{g}}$ & $6.42^{c}$ & $6.67^{f}$ & $12.87^{\mathrm{c}}$ & $11.98^{c}$ & $3.97^{\mathrm{c}}$ & $1.76^{b}$ & $381^{\mathrm{f}}$ & $10.42^{\mathrm{d}}$ \\
\hline & $\mathrm{D}_{4}$ & $40.22^{d}$ & $82.36^{\mathrm{fg}}$ & $6.51^{c}$ & 6.95 ef & $12.09^{\mathrm{d}}$ & $12.00^{\mathrm{c}}$ & $4.10^{c}$ & $1.96^{\mathrm{ab}}$ & $374^{\mathrm{h}}$ & $9.00^{\mathrm{e}}$ \\
\hline \multirow{4}{*}{6} & $\mathrm{D}_{1}$ & $39.11^{\mathrm{e}}$ & $78.23^{h}$ & $4.16^{\mathrm{d}}$ & $5.17^{\mathrm{h}}$ & $14.06^{b}$ & $13.17^{\mathrm{a}}$ & $5.22^{\mathrm{a}}$ & $2.18^{\mathrm{a}}$ & $346^{\mathrm{i}}$ & $15.89^{c}$ \\
\hline & $\mathrm{D}_{2}$ & $38.72^{\mathrm{e}}$ & $76.40^{\mathrm{i}}$ & $4.23^{\mathrm{d}}$ & $5.86^{\mathrm{g}}$ & $12.15^{\mathrm{d}}$ & $11.98^{b}$ & $3.89^{\mathrm{c}}$ & $1.97^{\mathrm{ab}}$ & $392^{f}$ & $8.50^{\mathrm{e}}$ \\
\hline & $\mathrm{D}_{3}$ & $37.76^{f}$ & $74.89^{\mathrm{g}}$ & $4.00^{\mathrm{d}}$ & $4.96^{h}$ & $14.64^{\mathrm{a}}$ & $13.02^{\mathrm{a}}$ & $4.89^{b}$ & $2.00^{\mathrm{ab}}$ & $342^{\mathrm{j}}$ & $19.46^{\mathrm{a}}$ \\
\hline & $\mathrm{D}_{4}$ & $39.26^{\mathrm{e}}$ & 75.77 ij & $4.10^{\mathrm{d}}$ & $5.08^{h}$ & $13.64^{b}$ & $13.20^{\mathrm{a}}$ & $5.18^{a}$ & $2.08^{a b}$ & $340^{j}$ & $17.30^{b}$ \\
\hline \multicolumn{2}{|c|}{ L.S.D $D_{0.05}$ period $(\mathrm{P})$} & 0.42 & 0.88 & 0.18 & 0.21 & 0.11 & 0.09 & 0.13 & 0.19 & 1.45 & 0.50 \\
\hline \multicolumn{2}{|c|}{ L.S.D 0.05 package type (D) } & 0.43 & 0.61 & 0.09 & 0.14 & 0.08 & 0.06 & 0.08 & n.s. & 1.14 & 0.86 \\
\hline \multicolumn{2}{|c|}{ L.S.D $D_{0.05} \mathrm{P}^{* \mathrm{D}}$} & 0.64 & 0.98 & 0.30 & 0.39 & 0.43 & 0.19 & 0.23 & 0.27 & 3.50 & 1.15 \\
\hline
\end{tabular}

Means in the same column followed by the same letters(s) are not significant according to L.S.D 0.05 values. 


\section{REFERENCES}

A.O.A.C. 1990. Official Methods of Analysis of the Association of Official Analytical Chemists. $15^{\text {th }}$ ed., published by Association of Official Analytical Chemists, Arlington, Virginia, USA.

Ali, Fatma F.M. 2012. Effect of K-fertilizer level, package type and storage period on some productivity and technological traits for five wheat varieties. Ph.D. Thesis, Fac. Agric., Alex. Univ., Egypt.

Arya, L. 2002. Nutritional changes in insect infested maize during storage. M.Sc. Thesis, Dept. Food Sci. and Nutrition, CSKHPKV, Palampur.

Baskin, C.C., J.C. Debouche and E.R. Cabrera 1987. The influence of packaging material, seed moisture content and storage environment on seed storability and performance. Newsletter of the Association of Official Seed Analysts, 61: 2-15.

Copeland, L.O. and M.B. McDonald. 1995. Seed Longevity and Deterioration. In. Seed Science Technology, Chapman and Hill. Pp. 181-220.

El-Aidy, A. Nadia, Soad, A. El-Sayed and Samia, A. Salama. 2001. Effect of package kind on cotton seed quality and viability during storage. J. Agric. Res., Tanta Univ. 27 (4): 765- 771.

El-Borai, M., A. Nadia, El-Aidy and M. El-Emery. 1993. Effect of different storage periods on seed quality of three soybean cultivars. J. Agric. Sci., Mansoura Univ. 15 (8): 2206- 2211.

El-Sayed, Soad A., M.E.A. Kineber and Eman, A. El. 2004. Effect of storage environment and package material on storability, yield and its quality of flax seeds. J. Agric. Res. 30 (3): 616- 638.

Gomez, K.A. and A.A. Gomez. 1984. Statistical Procedures for Agricultural Research. $2^{\text {nd }}$ ed. John Wiley \& Sons, New York, USA.

I.S.T.A. 1999. International Ruels for Seed Testing Association. Seed Sci., Technol. 27: 155- 165.
Ismail, I.M., M. Ragab, F.R. Hassanien and E.E. Abd ElRehem. 1988. Effect of drying and storage conditions on the quality of raw rice grains. Assiut J. Agric. Sci. 19 (5): 221- 238 .

Justice, O.L. and L.N. Bass. 1979. International rules for food testing. Seed Sci. Technol. 21: 25-46.

Mehmet, M., L. Karaog, A. Melek, G. Halis, Z. Kotancilar and E. Kamil. 2009. A comparison of the functional characteristics of wheat stored as grain with wheat stored in spike form. Int. J. Food Sci. Technol. 45: 38-47.

Narayan, R., G.S. Chauhan and N.S. Verma. 1988 a. Changes in the quality of soybean during storage. Part 1- Effect of storage on some physio-chemical properties of soybean. Food Chemist. 27 (1): 12- 23.

Odiemah, M. and S. Hafez. 1990. Effect of storage period and gibberellic acid on some characteristics of seed quality in spring wheat. Proc. $4^{\text {th }}$ Conf. Agron., Cairo, 15-16 Sept. 1: 225- 236

Ouda, S.A., M.S. Gaballah and M.A. El-Kholy. 2005. Predicting the effect of some yield stabilizing agents on increasing drought resistance in barley. J. Apple. Sci. 5 (8): $1378-1384$.

Pixton, S.W. 1980. Changes in Quality of Wheat During 18 Years Storage. 301-310. In. Controlled Atmosphere Storage of Grains. Shejbal (ed.). Elsevier Sci. Pub. Co. Amsterdam.

Saeeda, R.K.S., N. Khalid, A. Musarrat and G. Geen. 2010. Effect of house hold storage receptacles on physiochemical characteristics of wheat. Sarhad J. Agric. 26 (2): 151-160.

Tolba, S.A.E. and Soad, A. El. 2002. Viability and chemical component of grains of six maize genotypes as affected by ear and kernel rot diseases, under different agricultural practices. A. Agric. Res. 28 (1): 33-39.

Tomar, J.B. and M.P. Singh. 1986. Effects of temperature and moisture content during storage on the seed viability in rice. Ind. J. Agric. Res. 56 (11): 782- 787. 


\section{الملخص العربي}

\section{تأثير فترات التخزين ونوع العبوة على إنبات وصفات البادرة وإلتركيب الكيماوى لحبوب الشعير}

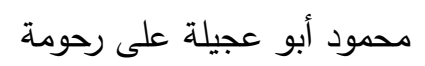

أجريت هذه الدراسة فى معامل المعهد العالى والمتوسط وزن الألف حبة (39.47\%) ونسبة الإنبات (63.66\%)

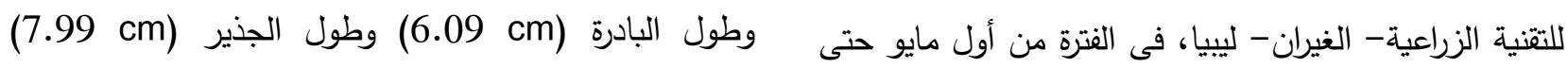
ونسبة البروتين بالحبة (11.97\%) ورقم السقوط (384.50) بينما أدى إلى ارتفاع المحتوى الرطوبى للحبوب (12.47\%) وكذلك نسبة الإصابة بالفيزاريوم (8.47\%). من ناحية أخرى فقد أظهر التداخل بين فترات التخزين

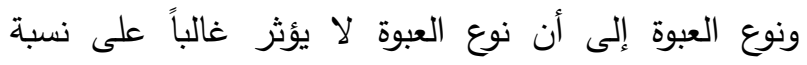

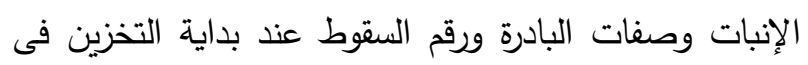
حين أظهر تخزين حبوب الثعير لددة ستة أشهر فى أكياس

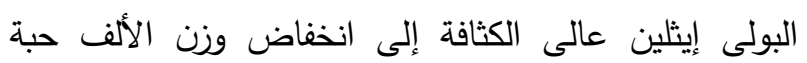

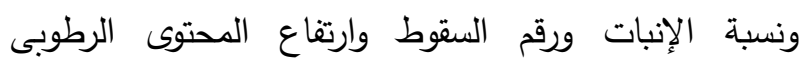

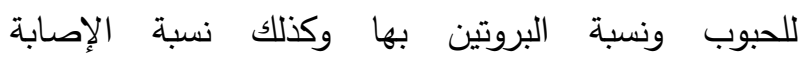

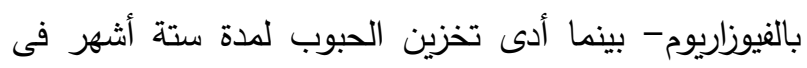
عبوات الجوت إلى انخفاض وزن الألف حبة ونسبة الإنبات

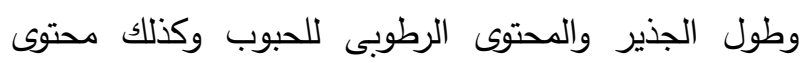
الحبوب من البروتين والدهون ونسبة الإصابة بالفيوزاريوم بدرجة أقل مقارنة بباقى العبوات المستخدمة أو ترك الحبوب العبون بدون تخزين.

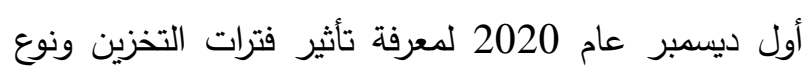
العبوة على نسبة الإنبات وصفات البادرة والتركيب الكيماوى لحبوب الثعير السداسى (Hordeum vulgare) صنف سيدى المصرى وقد نفذت التجربة فى تصميم تام العشوائية بنظام القطع المنثقة مرة واحدة فى ثلاث مكررات حيث مثلت فترات التخزين الأربعة عامل القطع الرئيسية عشوائياً كالتالى

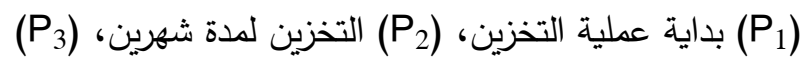

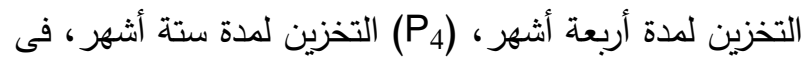

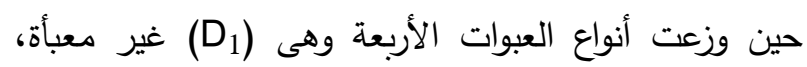
(D2)

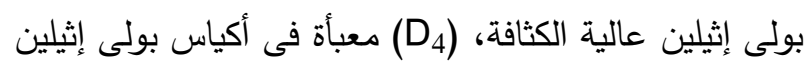
منسوجة. وتىت الدراسة تحت الظروف العادية من حرارة

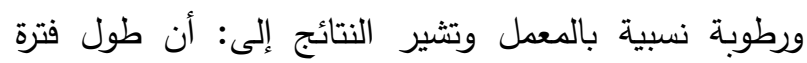

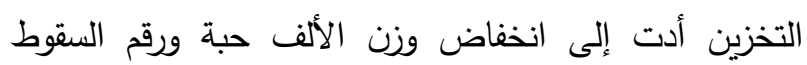

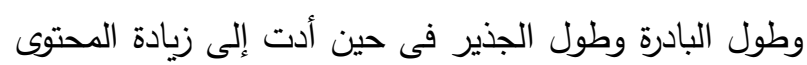
الرطوبى للحبوب وكذلك نسب البروتين والدهون والرماد ونسبة الإصابة بالفيوزاريوم من جهة أخرى أدى تخزين الحبوب فى أكياس البولى إيثلين عالى الكثافة إلى انخفاض الئل 